\title{
The shadow of the "Great Earthquake" on a sustainable Bucharest. Shared responsibilities and disaster risk management
}

\author{
Bogdan Suditu ${ }^{* 1,3}$, Mihai Șercăianu ${ }^{2,3}$, Marina Neagu ${ }^{3}$, Ioana Nenciu ${ }^{4}$ \\ ${ }^{1}$ University of Bucharest, Romania \\ ${ }^{2}$ Technical University of Civil Engineering Bucharest, Romania \\ ${ }^{3}$ MKBT: Make Better, Romania \\ ${ }^{4}$ City Building Inspector at State Construction Inspectorate, Romania
}

Bucharest is located in Romania's most active seismic area. In the past, the city has been significantly affected by a few earthquakes, including the 1977 one, which was one of the strongest and caused the most significant number of human victims and material damage. The concentration of population, old or high buildings means that in Bucharest, living with high seismic risks is one of the most important economic and socio-demographic vulnerabilities. The shadow of the great earthquake is constantly present here in debates and public actions, but the operationalisation of disaster risk management measures are not yet at optimum in terms of implementation actions. This research presents a critical assessment of regulatory and operational measures used to identify vulnerable seismic buildings, the responsibilities of the public and private stakeholders involved, and the way in which each of latter assumes and implements the first.

Key Words: sustainable Bucharest, earthquake, urban policies, disaster risk management, shared responsibilities, civic action

Article Info: Received: November 19, 2019; Revised: January 24, 2020; Accepted: January 25, 2020; Online: May 23, 2020.

\footnotetext{
*Corresponding author

Address: Department of Human and Economic Geography, Faculty of Geography, University of Bucharest, N. Bălcescu Av., no. 1, Bucharest, 010041, Romania.

Phone: +04021.305.3843 | Email: bogdan.suditu@unibuc.ro
}

(C)2020 Human Geographies; The authors

(9) $\stackrel{(0)}{r}$ This work is licensed under a

Creative Commons Attribution 4.0 International License. DOI:10.5719/hgeo.2020.141.1 


\section{Introduction}

In Romania, like all states located in seismic areas, the issues related to the effects earthquakes have on cities and societies are subject to public policy and scientific research. The focus of these research activities is to identify vulnerabilities and adapt the construction rules and urban management so that the impact and damage caused by earthquakes could be reduced. The city of Bucharest is recognised as one that is often affected by strong earthquakes (e.g. 1940, 1977, 1991), and concern for the next, Great Earthquake, mobilises public authorities, citizens, researchers, and others.

Bucharest's seismicity and vulnerability have been the subject of multiple research with complementary themes to the present paper. The diversity of methodological approaches, from field research-based analysis or factorial and GIS analyses respectively, the orientation of research into social vulnerabilities or built space, provides relevant scientific literature on Bucharest' vulnerabilities and sustainability. Thus, many studies aimed to identify and analyse the social and built-in components that led to the vulnerability of this city (Marmureanu et al., 2010; Armaș et al., 2017) in the context of an imminent new earthquake. This research focuses on analysing the age of constructions and the socio-demographic specific dysfunctions of the city. In this respect, although complementary, the diversity of results is determined by the use of different analyses of Bucharest' vulnerability and sustainability. They are based on either multi-criteria approaches (Armaș et al., 2012, 2013, 2014; Toma-Danila et al., 2015), on models of damage estimation (Duzgun et al., 2011; Lang et al., 2012), on GIS analyses of statistics and territorial databases (Rufat, 2009; Chen et al., 2010) or the analysis of sustainability and vulnerability from the perspective of urban planning (Petrișor et al., 2010; Ianoș et al., 2017). The common research objective is to identify vulnerable urban territories and establish the hierarchies and characteristics of each urban area.

In relation to the mentioned works, our study aims to use technical analysis of urban actors' responsibilities (public authorities, inhabitants, civil society) in order to limit the vulnerability of Bucharest. It is based on the results of the "ALERT Seismic Risk Awareness Project" project implemented between 2016 and 2018, concerning the buildings classified as having a high seismic risk, following their technical assessment based on technical standards, namely Seismic Risk Class I buildings. Up until the Law no. 223-2018 which modified and completed the Governmental Ordinance no. 20/1994 on the measures for reducing the seismic risk of existing buildings was approved, the buildings that had been included in the I class of seismic risk by a technical expertise report were further subdivided into two subcategories, namely "Seismic Risk Class I with public danger" and "Seismic Risk Class I". The project intends to: explain the context of the creation and evolution of urban policies in order to ensure the sustainability of Bucharest and to reduce its seismic risk, identify and quantify the vulnerability degree of residential buildings as well as to provide critical analysis of shared measures of urban governance and disaster risk management. 


\section{Bucharest's seismicity and sustainability: real past and uncertain future}

According to the Romanian National Institute for Earth Physics (NIEP), Bucharest is located in the most active seismogenic area of the country. Its population density and old buildings concentration means that when living here, the seismic risk is one of the most critical economic and socio-demographic vulnerabilities.

From the last official Population and Housing National Census (INS, 2011), 132,171 housing buildings were identified in Bucharest, including 844,541 dwellings units. Of these, 86,662 housing buildings $(65.2 \%$ of the total of Bucharest buildings) were built before 1980, and 31,511 housing buildings (23.7\%) were built before 1945 . Unfortunately, there is no public information about the number of people living in each of these types of dwellings, respectively in buildings constructed in different periods. The information from Bucharest City Hall website regarding technically evaluated buildings and classified as Seismic Risk Class I, highlights the year of construction, floor numbers and number of dwellings, but not the number of inhabitants or other detailed data about their occupancy status (Bucharest General Municipality website, 2018).

Seismic risk in Bucharest is highlighted statistically by a list of evaluated buildings which contains the four risk classes, identified based on engineering tests which wete approved based on technical-juridical norms. Each of these classes is defined and explained by the extent of potential damage following an earthquake, ranging from structural collapse down to lack of degradation. These lists do not only identify buildings of different heights and a different number of apartments but indicate vulnerable buildings that are part of city built-up tissue.

These buildings can put people's lives in danger every day, and a structural intervention must be conducted to ensure their stability and safety. The degree to which the seismic risk problem in Bucharest goes ignored is problematic, considering its magnitude and degree of urgency. With nearly 2 million inhabitants and located only $170 \mathrm{~km}$ away from the Vrancea seismic source, Bucharest is considered to be the capital city with the highest seismic risk in Europe. Even though there are no accurate official data about the number of inhabitants affected in some way by buildings with seismic risk, the debates on the effects of an imminent high-intensity earthquake take into account the existence of a large number of victims as well as the occurrence of significant material and human damage (Lang et al., 2012). Victims may be occupants of buildings profoundly affected by an earthquake (owners, tenants, employees of companies located in these buildings), but also of passers-by (especially in the case of buildings collapsing along the heavy circulating arteries) or living in neighbouring buildings (of smaller heights with public or cultural functions like kindergartens).

The study Housing in Romania. Towards a National Housing Strategy realised by the World Bank and based on data from the Romanian Ministry of Public Works, Development and Administration, former Ministry of Regional Development and Public Administration, (WB/MDRAP, 2015) shows that nationally there are over 
10,000 dwelling units registered in the Seismic Risk Class I, of which more than half are in Bucharest. At the time this paper is being written, 6,005 dwellings units are located in a Seismic Risk Class I building. Apart from these, there are commercial and cultural spaces whose operating license was withdrawn, based on Law no. 282/2015 that amends and completes the Government Ordinance no. 20/1994 on reducing the seismic risk of existing constructions. The last amendment of the specific legislation was done through Law no. 223/208 which modified the Governmental Ordinance no. 20/1994 when the syntagm "Class R(s) I of public danger" was eliminated for all buildings classified as such and they were assimilated and introduced in the class R(s) I. Before these legislative changes, buildings were considered to be "of public danger" if they met at least two of the criteria: a. they contain public spaces, covering more than 50 usable sq.m., occupied temporarily or permanently and which are not used for living (e.g. ground floor areas used for commercial purposes); b. they have a $\mathrm{P}+3$ height regime and contain a minimum of 10 dwellings; c. they are located in settlements where the maximum value of land acceleration considered in earthquake projection ag, according to Romania's zoning map of the P100-1 Code for seismic projection, is of $0.15 \mathrm{~g}$ or higher. Until August, if 2018 these were the only category of seismic risk buildings that were eligible to be included in annual governmental programs aimed at designing and implementing works for intervening in reducing seismic risk. By regrouping the existing categories in a single level I of seismic risk class, the goal was to increase the eligibility and ease access to consolidation programs for all buildings with a significant risk of collapse and to mobilise public investments and as well as ownwers' interests.

In Bucharest, there is a significant built-up stock that is in danger of collapsing or suffering significant damage in case of an earthquake. Out of the 346 buildings classified as Risk Class I, approximately 90\% have outstanding architectural heritage value, being located in central protected areas (Figure 1a). This aspect denotes both the value of the built-up environment in its current form and the importance of regulating it. Regulations include structural interventions, where the heritage value of the building becomes an important constraint for the consolidation process with the added burden of the absence of a viable financial and technical mechanism. In such situations, real estate interests conflict with construction restrictions applied in these areas and buildings. Bucharest's central area concentrates the most significant number of old buildings, with many being evaluated and classified as emergency categories or risk classes (Figure 1b).

In the central area, as a result of systematic nationalisation (between 1949 and 1950) and poor housing management during the communist period, two significant phenomena were recorded:

- the majority of the housing stock (state-owned) has deteriorated and has not benefited from constant investments meant to keep it safe/secure;

- between 1950 and 1989 the state intervened punctually by building dwellings in new blocks, and the housing stock has not been significantly modified (except for the demolitions carried out to make room for the construction of the new Civic Centre, or other urban ensembles such as Palace of Romanian Communist Party for example). 


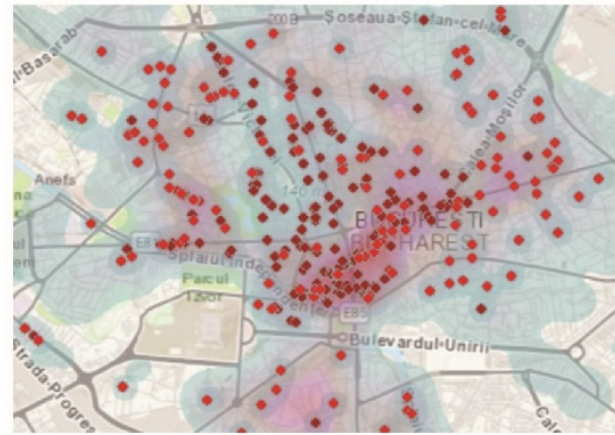

P100-3/2008 code

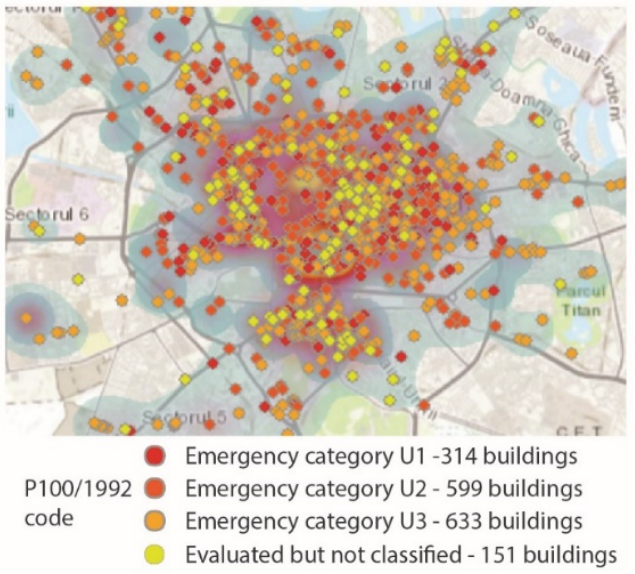

Figure 1. Distribution of buildings evaluated based on the P100-3/2008 (a) and P100/92 seismic codes (b)

Source: Authors processing and representation based on List of buildings technically evaluated and classified into seismic risk classes - Municipal Administration for Consolidating Buildings with Seismic Risk Bucharest / General Municipality 2018

At the end of the communist period, more than $1 / 3$ of dwellings built in Bucharest before 1945 were located in its central area (21,038 of the 43,441 buildings with dwellings). Of these, $84.39 \%$ were buildings with ground floor and maximum up to one floor ( $\mathrm{GF} \sim \mathrm{GF}+1$ floor). Also, 254 of the 281 blocks with 57 floors built before 1940, respectively 70 of the 156 blocks over 8 floors built during the same period were located in the city's central area (Figure 2).

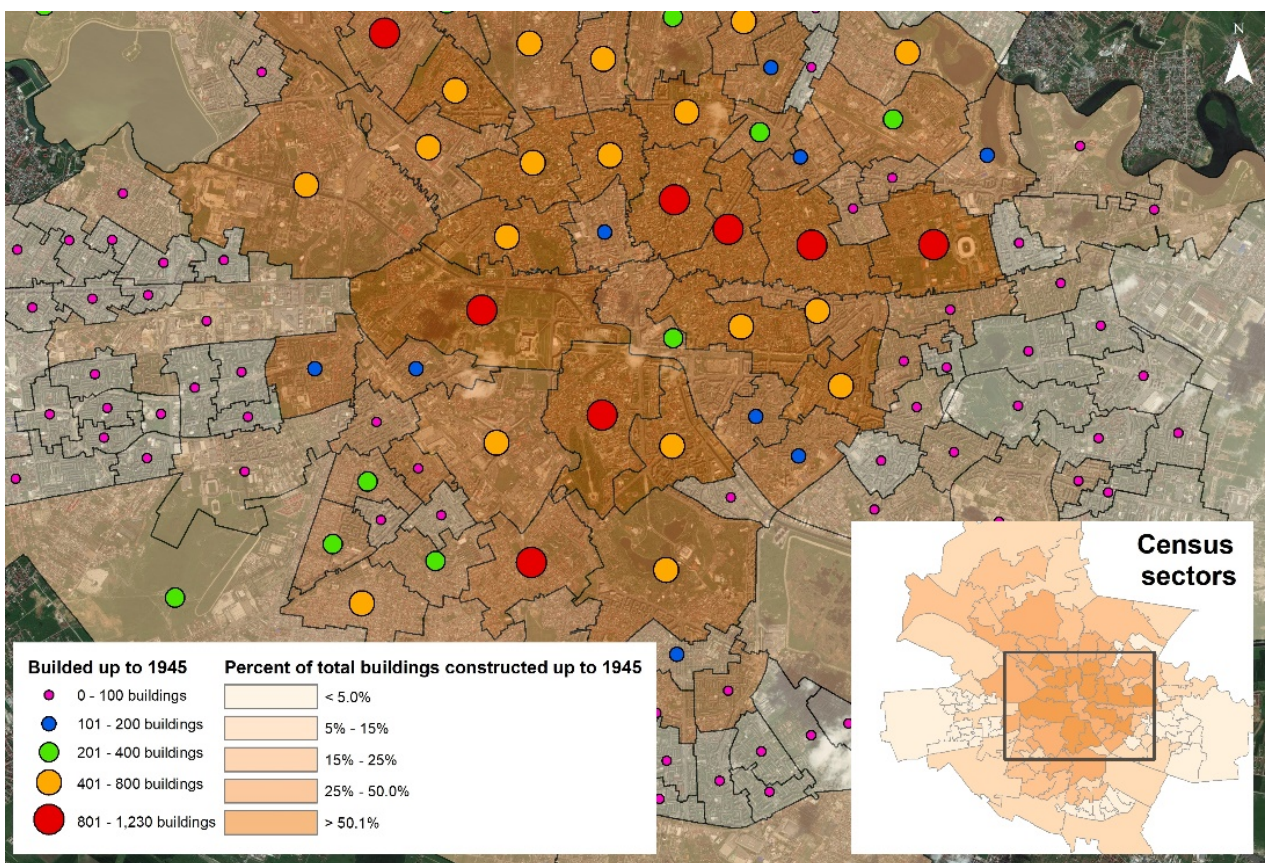

Figure 2. Constructions distribution built up to 1945 in the central perimeter of Bucharest Source: Authors processing and representation based on the 2011 Population and Housing National Census 
After 1990, the process of restoring properties from the central area was slow, which did not immediately create a spirit of civic responsibility among the new or old owners regarding good building management and structural safety. Observations following the ALERT Project highlighted an attitude of indifference relating to disaster risk management, most often encouraged by the state with its lack of or inconsistency in action (both at a central and local level). To illustrate the scale of the urban vulnerability we name the case of Magheru - N. Bălcescu Boulevard, a perimeter located in the centre of the city with 60 buildings listed as historical monuments and belonging to the seismic Risk Class I. On this boulevard there are 4 major cultural points of interest, Cinema Patria, Cinema Scala, Notarra Theatre and Cinema Studio - all of them closed according to Law no. 282/2015 - as well as many other commercial spaces located on the ground floor of buildings that received the "red dot". Considered altogether, these cultural spaces have a capacity of more than 2,800 seats and are located in buildings with 8 to 10 floors. On the upper floors of these buildings, hundreds of dwelling units were identified, often rented trough "Airbnb" or "HomeAway" platforms. In addition, the perimeter is one of Bucharest's most crowded area, with high pedestrian and road traffic, a situation that would generate even more human and material losses in case of major seismic events.

\section{The "Red dot" or assessing seismic risk - standards and evaluation practices}

The "red dot" is what technical experts and structural design engineers call informally the buildings that have been evaluated based on Romanian Code for seismic assessment of existing buildings P100-3/2008 and were framed as having a Seismic Risk Class I, for constructions with a high risk of collapse on seismic designing force.

To identify areas potentially affected by a high-intensity earthquake, we must look at the history of seismic design codes in Romania. The first provisional regulations for an anti-seismic structure design were published in 1941 after the Vrancea earthquake from November, $10^{\text {th }} 1941$, based on the 1938 Italian codes. Other attempts for provisional regulations or standardisation followed in 1945 and 1958. On July, $18^{\text {th }} 1963$, P13/63 Provisory Norm for Civil and Industrial Constructions Design in Seismic Regions, the first anti-seismic norm was adopted. The document was drawn considering the destruction brought by the 1940 earthquake, observations from other countries with similar conditions, and observations or recommendation from international conferences, even though at that time there were no electronic records of Romanian seismic movements. It was followed on December, $31^{\text {st }} 1970$ by the approval of a revised version entitled Norms for Design of Civil and Industrial Constructions in Seismic Regions, P13/70, even if it was later observed that the implemented changes resulted in a conventional seismic force reduction by approximately $20 \%$ on structures composed of reinforced concrete frames (Cretu et al., 2006). 
Recordings of land acceleration at the seismic station INCERC-Bucharest during the earthquake from March, $4^{\text {th }} 1977$, as well as field observations, led to the substantiation of two regulations: Normative for anti-seismic design of social housing, cultural, agrozootechnical and industrial constructions, P100 / 78 (with experimental application) and later transposed into P100 / 81 Normative. Subsequently, the $P 100 / 91$ and $P 100 / 92$ norms were elaborated based on further specialised research referred to as Normative for anti-seismic design of housing, social, cultural, agrozootechnical and industrial construction. In addition, research has been validated by land acceleration records from national seismic networks for the earthquakes of August, 30 $0^{\text {th }} 1986$, May, 30 $0^{\text {th }}$ and $31^{\text {st }} 1990$ respectively. As a novelty in $P 100 / 92$, apart from seismic protection levels, the constructions in emergency categories were distinguished by classes of importance and frames of seismic risk. The harmonisation of national norms with the format of European code EC8 (SR EN-1998-1: 2004) was made by the seismic design code Part I Design provisions for buildings, indicative P 100-1/2006 and the seismic design code "Part III - Provisions for seismic assessment of existing buildings, indicative P100-3/2008. P100-3/2008 is a mandatory guide for seismic expertise and rehabilitation of existing buildings. Finally, the technical regulation called Seismic design code - Part I - Design provisions for buildings, indicative P100-1/2013 is approved. This technical regulation stipulates the seismic zoning of the Romanian territory in terms of peak acceleration values used for structural design ag, with an average recurrence interval of 225 years, i.e. $20 \%$ probability of overtaking in 50 years.

The earthquake series from May, $30^{\text {th }} 1990$ - December, $2^{\text {nd }} 1991$, contributed to the re-emerging awareness of the political legislature and public administration authorities to seismic risk awareness and led to the establishment of the first consistent norms regarding interventions on affected buildings.

Thus, in response to the damage caused by these earthquakes, the Government Decision (G.D) no. 709 from October, $10^{\text {th }} 1991$ Measures for public and private buildings consolidation affected by earthquake indicated the funding sources needed to finance investment related to consolidation design and execution of earthquake-damaged buildings. The only proactive measure on building consolidation and seismic risk reduction for the existing building stock was the recommendation of that all potentially vulnerable buildings should be evaluated. The decision indicated measures set up by technical expertise for each of these buildings which aimed to consolidate them and ensure their proper functioning, but especially at protecting the occupant's lives and those who travel daily alongside them. The expertise cost for these buildings according to G.D. $709 / 1991$, was borne by the central state administration budget in $75 \%$ cases for private property dwellings, respectively $50 \%$ for state housing stock, with the condition that building owners would undertake the consolidation works suggested by the technical expertise. This explains why a large number of technical expertise was carried out in 1992-1997, and the first structural interventions were carried out in some buildings that had been evaluated in the process. Almost 1,500 buildings were evaluated under the P100/92 design standard norms. The P100/92 norms frame seismic risk constructions in emergency 
categories (U). Emergency category $\mathrm{U}$ recommends a maximum period of time to start the structural consolidation works: U1 - maximum 2 years, U2 - maximum 5 years, U3 - maximum 10 years, U4 - maximum 15 -20 years.

After that, with the adoption/promulgation of P100-3/2008 norms that divides seismic risk constructions into 4 seismic class risk categories (Rs) another set of buildings were evaluated, but far too few compared to the existing stock. The four classes are as follows: Class RsI for constructions with a high risk of collapse on seismic designing force; Class RsII for constructions which under the seismic designing force can present major structural damages but the loss of stability is unlikely; Class RsIII for constructions which under the seismic designing force can present structural damages that do not impact the structural safety significantly but for which, the non-structural damages can be significant; Class RsIV, for constructions which have an expected seismic response similar to the ones newly constructed - designed according to the current regulations.

Presently, 346 buildings are classified as Seismic Risk Class I, and more than 400 buildings are classified as Seismic Risk Classes II and III, and their deterioration may have worsened in the meantime (Table 1 and figure 3). Experts certified by the Ministry of Public Works, Development and Administration conducted this technical expertise.

Table 1. Comparison between the year of expertise (updated in the meantime) and P1003/2008 Risk Classes

\begin{tabular}{lcc}
\hline & \multicolumn{2}{c}{ Seismic Risk Class I buildings } \\
\hline Initial expertise year & No. & $\%$ \\
$<=1993$ & 202 & $58 \%$ \\
$1994-1995$ & 58 & $17 \%$ \\
$1996-2000$ & 49 & $14 \%$ \\
$2001-2010$ & 15 & $4 \%$ \\
$2011-2017$ & 22 & $6 \%$ \\
\hline
\end{tabular}

Source: Authors processing based on List of buildings technically evaluated and classified into seismic risk classes (2018), Bucharest General Municipality

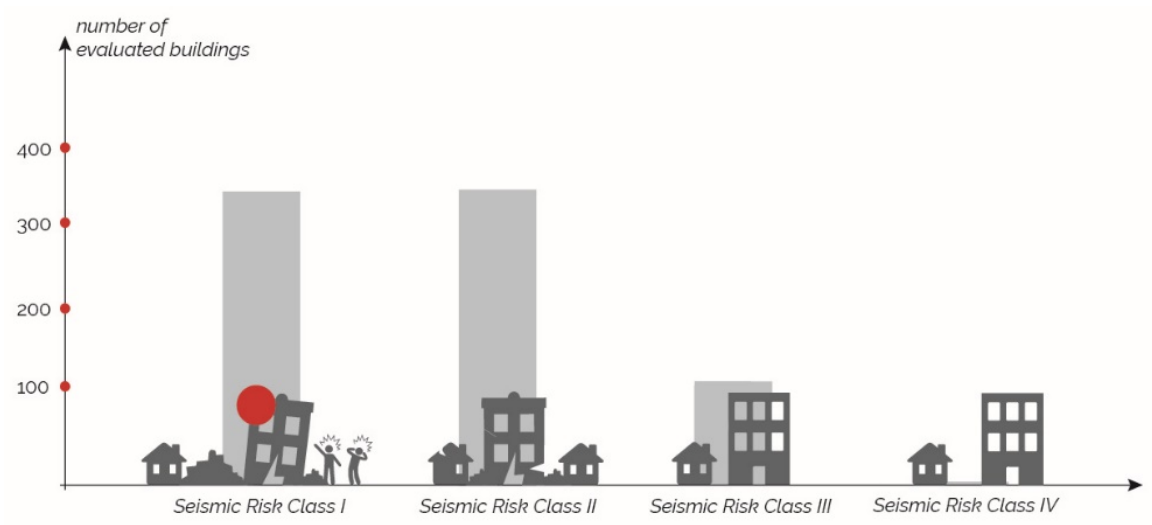

Figure 3. Buildings evaluated through the $\mathrm{P} 100-3 / 2008$ norm and Risk Classes distribution Source: Authors processing and representation based on ALERT Project Results 
In the context of promoting public policies aimed to privatise the state housing stock, and increasing demands for the restitution of nationalised house and sale of buildings administered by former ICRAL (in communism period Enterprise of Construction, Distribution and Housing Management), reducing the seismic risk of existing constructions and establishing responsibilities for the consolidation of residential buildings is a legislative priority for the Government. Thereby the Government Ordinance no. 20/1994 on measures for seismic risk reduction on existing constructions has been elaborated and adopted. This is a normative act currently modified by Laws no. 84/2015, no. 282/2015 and no.223/2018. In the period following the approval of the Government Ordinance no. 20/1994, at the initiative of former ICRAL, numerous technical expertise were made for dwellings meant to be sold to tenants, following the legislation in force at that time. Through the Government Ordinance no.20/1994, the Annual Action Program for the design and execution of consolidation works on multi-storey dwelling buildings, classified by a technical expertise report as belonging to seismic risk class I was implemented, a funding program currently managed by the Ministry of Public Works, Development and Administration. The buildings evaluated under the P100/92 design standard norms are not subject to multiannual consolidation programs but can pose a real threat in the event of an earthquake.

\section{Vulnerable Bucharest - ALERT Project methodology and partial results}

ALERT is a sustained approach to seismic risk awareness in Bucharest. From 2016 it stimulates civic involvement by data crowdsourcing and resources publishing for those potentially affected using the seismic-alert.ro platforms. Residents are involved in the development process of new public seismic risk reduction programs, and technical expertise is mobilised for producing analyses and advocacy documents to illustrate the severity and scale of seismic risk. The data collection component of the ALERT project was carried out with the support of volunteers, both from academia (teachers and students from University of Bucharest, Faculty of Geography and Technical University of Civil Engineering in Bucharest), as well as non-academic (inhabitants, administrators of buildings with seismic risk).

During the fieldwork phase, started in May 2016, 261 owners' associations were contacted, and data was gathered through an online questionnaire developed on the platform. The source of information collected in this manner, consists exclusively of data and declarations from owners, tenants, or buildings administrators, together with the information included in the Bucharest Municipality official list of evaluated buildings. Discussions and debates were conducted, either by field research or by organising face-to-face meetings and group discussions with citizens potentially affected by seismic risk issues (Figure 4). The present paper explores data collected in the ALERT Project until the end of 2017 on 307 buildings from the 346 Seismic Risk Class I buildings, translating in a coverage rate of about $88 \%$ (Table 2 ). 


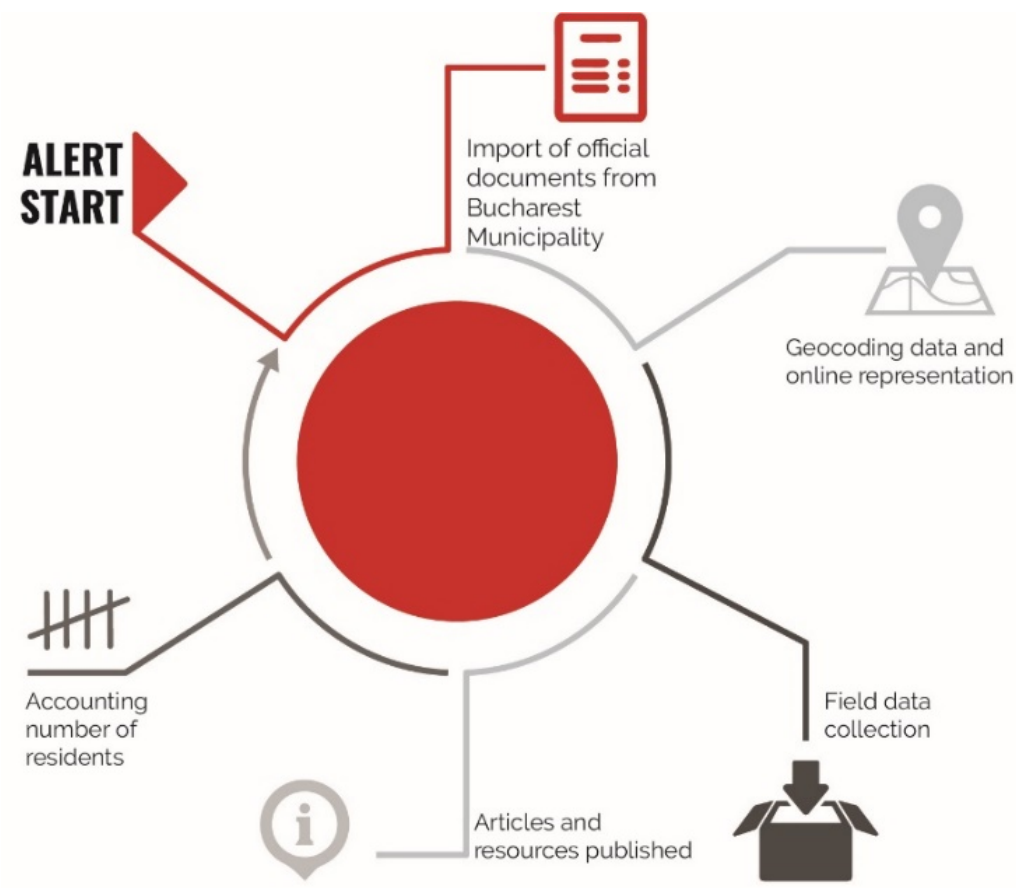

Figure 4. ALERT project methodology phases

Source: Authors representation based on ALERT Project Results

Table 2. Distribution of evaluated buildings Seismic Risk Class I by number of apartments and number of floors

\begin{tabular}{lcclcc}
\hline & \multicolumn{2}{c}{$\begin{array}{c}\text { Seismic Risk } \\
\text { Class I buildings }\end{array}$} & \multicolumn{2}{c}{$\begin{array}{c}\text { Seismic Risk Class } \\
\text { I buildings }\end{array}$} \\
\hline $\begin{array}{l}\text { Apartments per } \\
\text { building }\end{array}$ & No. & $\%$ & No. of floors per building & Nr. & $\%$ \\
$0-3$ & 75 & 21,68 & GF $\sim$ GF +1 floor & 67 & 19,36 \\
$4-8$ & 98 & 28,32 & GF+2floors $\sim$ GF +3floors & 139 & 40,17 \\
$9-15$ & 59 & 17,05 & GF+4floors $\sim$ GF+5floors & 58 & 16,76 \\
$16-25$ & 50 & 14,45 & More than GF+6floors & 82 & 24 \\
$>25$ & 64 & 18,50 & & & \\
\hline
\end{tabular}

Source: Authors processing based on ALERT Project Results

One of the ALERT Project' objectives was to quantify the number of people living under seismic risk, namely, to identify vacancies in the buildings classified in Seismic Risk Classes I. Thus, from the data obtained from field surveys and the data recorded on the www.seismic-alert.ro site offered by administrators or owners /tenants of the mentioned buildings, it resulted that in the 307 buildings analysed so far, live more than 8,063 people, a fact which mathematically confirms that the estimated population from buildings in Seismic Risk Class I is of about 10,000. Starting from the official list provided by the Bucharest Municipality (PMB), 346 listed buildings were identified, geocoded in web-GIS environment and analysed, containing approximately 6,500 apartments. Under the occupancy status, we noted that 880 apartments - $16.19 \%$ of mapped apartments - are occupied by tenants, and 1,585 (29.16\%) are free or unused. 


\section{Owners, tenants, banks and local authorities - the antithesis of economic attitudes and perspectives}

The high number of buildings - due to a mix of functions and owners (both private and public) - led to an even more complex management. The service spaces identified in these categories include, among other things, high-capacity cultural functions such as cinemas and theatres. The thematic debates organised with citizens who live in buildings classified as vulnerable to earthquakes have revealed other perspectives on seismic risk, in addition to what emerged from the processed survey data.

The most apparent issue presented by people living in these buildings is a feeling of fear and sense of helplessness: the owners feel overwhelmed by the situation, they do not know how they can act to consolidate their building. Even in cases where the owners are well informed, they have great difficulty working together with all the apartment owners in the building - they function in a coownership system - because some of them do not live there anymore (perhaps even in Romania), and others are foreign citizens or legal entities that are hardly identifiable and contactable, and a significant number (including the local authority as owner) do not get involved. It seems there is no contact person or entity to which owners can address for information, advice and/or support in accessing the consolidation funds.

Some owners are elderly and consider that as they do not have much more to live anyway, they see no point in moving or consolidating - a sad and cynical perspective on risk. Others live with the fear, amplified by every new earthquake, however small, recorded in Romania, or similar events from abroad presented by the media. A synthesis of opinions and information from field discussions allowed us to create two categories of owners:

- Proactive persons, interested in the issue of building management and consolidation solution through a Governmental Program or other financial sources

- Uninformed, distrustful, or people disinterested in finding solutions for the structural consolidation and disaster risk management

Most often, limitations or disinterest of owners and owners' associations for constructive consolidation interventions stem from financial motivations. From this point of view, the initial interest in obtaining the "red dot" for their building, respectively the creation of the fund meant to carry out repairs and other safety actions, led to unique practices of those involved. Owners, owners associations, or representatives' statements have highlighted many types of real estate speculation aimed at vulnerable buildings. They mentioned that starting with the 1990s some landlords opted openly for obtaining a first-class seismic risk status, in the hope of a financial devaluation of the block, which would allow them, in the long run, and by successive acquisitions, to control the entire condominium. Others saw the "red dot" as an advantage, hoping to benefit from funds that would allow them to upgrade their properties. Real estate interests also worked the other way around: there have been identified cases in which owners of commercial premises on the 
ground floor are unable to continue their activity as a result of Law no. 282/2015, a law that does not allow for commercial activities in buildings with seismic risk. Others commissioned new expertise for the first-class seismic risk declassification, sometimes even without consulting and involving all the owners from the buildings' upper floors. The fact that properties at risk cannot benefit from insurance and cannot be the subject of loans, banks credits, or help from other private financial institutions makes them untradeable on the market, and their value drops considerably. Block administrators have also confirmed that there are situations where real estate investors acquire property in buildings with seismic risk, spruce up their interior but do not do any structural interventions and rent them at a daily rate or for a limited time at considerable prices. This is also confirmed by the property listed for rent through Airbnb or similar platforms, which contain many apartments in "red dot" building.

\section{Disaster Risk management - actors and responsibilities assumed de jure and de facto}

In truth, responsibilities for disaster risk management are shared between several central or local public institutions and landowners. Thus, the Ministry of Public Works, Development and Administration, in its capacity as building regulation authority, will act, at stakeholder's request, to:

- approve the technical intervention solutions for intervening in buildings in the first class of importance (hospitals, anti-seismic shelters, headquarters of civil protection institutions), whose functionality, during the earthquake and immediately after the earthquake, must be fully assured,

- endorse the technical intervention solutions for existing buildings with housing function, classified as Seismic Risk Class I, nominated in the annual action programs approved by a Government Decision, according to the law.

The Ministry of Public Works, Development and Administration organises the National Commission for Seismic Engineering, referred bellow as National Commission, a specialised technical body, without legal personality, with advisory, analytical, and prior notice role. The National Commission is made up of technical engineer experts and specialists in construction, installations facilities, and architecture, appointed at the proposals of higher education and researchdevelopment institutions, professional associations, representative employers' associations, and public administration authorities with functions in the field.

At a local administration level, the Mayor of Bucharest, like any other mayor, has an obligation to act for the:

- identification and inventory of potentially vulnerable buildings;

- notification of owners, individual or legal persons, owners' associations, as well as, legal entities that manage a seismically vulnerable building, either in its entirety or part of it, regarding their obligation to act united for carrying out technical expertise of the whole building.

Also, the Bucharest Emergency Management Committee acts to: 
- develop programs and interventions in order to reduce the seismic risk of existing constructions;

- create anti-seismic education programs for the population

Building owners and administrators, individual or legal persons, and owners' associations have an obligation to:

- track the structural behaviour of the building they own or manage, and periodically update the building's technical charter;

- initiate the technical expertise (conducted by certified technical experts), for mechanical strength and stability requirements, of existing structures with insufficient levels of protection against seismic actions, degradations or damages due to seismic actions in order to classify them in the proper seismic risk class and underlain future intervention measures.

Private owners, and public property administrators located on the ground floor and/or, basement and/or other levels of multi-storeyed buildings with more than three floors, constructed before 1978, must act proportionally and jointly with the other apartments owners or associations, to imitate technical expertise related to structural resistance for the entire building within 2 years from the date that Government Decision 20/1994 was adopted.

In 2018, two years after the deadline set in 1996 had passed, many of these actions had not been taken into consideration both by the public and private actors involved in the process, thus increasing Bucharest's vulnerability.

\section{Conclusion. Bucharest's real sustainability and vulnerability degree}

In order to know Bucharest's real situation, a mandatory seismic evaluation and assessment must be implemented for all constructions older than 20 years. Those built before 1978 must have the priority, as this is a reference year due to the first anti-seismic design norms(P100-78) being legally approved and improved after the '77 earthquake. Sometimes, out of three construction bodies of a building, built in the same year with the same engineering design and technical solution, only one has been evaluated and included in seismic risk class I, but, in case of a high-intensity earthquake, all three bodies can be equally affected by the event. Owners of buildings (individual or legal persons), owners' associations, as well as legal entities that manage the building, must be made to initiate the technical expertise conducted by experts. Also, technical construction building charts must exist and be periodically updated. Just like any other identification form owned by a person, any building, regardless of the type of use, must have their proper documents. The technical construction building chart is structured in separate chapters, which contain the documents related to building design, execution, reception, operation, maintenance, repair and use of the structure and related facilities over time. If parts of the documentations are missing or are incomplete, the information needs to be filled with updated plans, results of non-destructive tests, or results of the calculation process. It is essential that any modifications to the structure must be written down in the technical document. 
All constructions must be evaluated and assessed for seismic risk classes based on a single seismic code, namely P100-3/2008, or on an updated version of it. The over 1,500 buildings evaluated under the P100/92 design standard norms and classified in emergency categories had to be consolidated in a period of time of a maximum ranging from 2 to 20 years. This interval already expired without the works even starting and, furthermore, these buildings are not eligible to be funded through the multi-annual building consolidation program because they are not evaluated according to the latest seismic assessment code in force.

Twenty-six years after the implementation of the Government Ordinance no. 20/1994, the reduced number of buildings consolidated through the Annual action program for design and execution of consolidation works on multi-storeyed dwellings, assessed by a technical expertise report in Seismic Risk Class I, carried out by Romanian Government, as well as the non-application of the contraventions established by the mentioned normative act, were a negative signal for the targeted population. The result was the lack of interest, especially from a safety perspective, of occupants from buildings with seismic risk.

In situ research, anti-seismic normative analyses and public debates, enumerated within the project, confirmed that Bucharest is a vulnerable city that, as the public and private actors involved do not assume their responsibilities and act on them, becomes more and more vulnerable. For a sustainable city and better disaster risk management, measures are necessary to be identified, encouraged, and implemented. Consolidation of vulnerable buildings is mandatory, and in some case, the reconstruction of those that are no longer safe. Other identified measures refer to the improvement of the regulatory framework regarding the condominium management; harmonisation of the legislation that provides financial resources for repairs and consolidation and strengthening the control measures for vulnerable buildings and perimeters; development of new measures and alternative financial and banking instruments for local authorities and/or owners associations, for financiang works to strengthen and repair, respectively harmonisation and development of legislation on urban renovation measures.

\section{Acknowledgements}

This work was supported by the project "ALERT - Seismic Risk Awareness Project 2016-2018 www.seismic-alert.ro" initiated by MKBT: Make Better and implemented with the Romanian Centre for Innovation in Local Development. Authors have full rights to use, interpret and disseminate the project results.

\section{References}

Armaș, I. (2008), "Social vulnerability and seismic risk perception. Case study: The historic center of the Bucharest Municipality/Romania", Natural Hazards, vol. 47 , no. 3 , p. $397-410$. 
Armas, I. (2012), "Multi-criteria vulnerability analysis to earthquake hazard of Bucharest, Romania", Natural Hazards, vol. 63, no. 2, p. 1129-1158.

Armaș, I. and Gavriș, A. (2013), "Social vulnerability assessment using spatial multi-criteria analysis (SEVI model) and the Social Vulnerability Index (SoVI model)_A case study for Bucharest, Romania", Natural Hazards and Earth System Sciences vol. 13, p. 1481-1499.

Armas,, I. and Radulian, M. (2014), "Spatial multi-criteria risk assessment for earthquake hazards in Bucharest, Romania" in Earthquake hazard impact and urban planning, DM Boștenaru, I Armaș, and A Goretti (eds), Springer, Dordrecht, p.127-149.

Armaș, I., Toma-Dănilă D., Ionescu R. and Gavriș, A. (2017), "Vulnerability to Earthquake Hazard: Bucharest Case Study, Romania", International Journal of Disaster Risk Science, vol. 8, no. 2, p. 182-195.

Bucharest General Municipality (2017), List of buildings technically evaluated and classified into seismic risk classes, 10 December 2017, shorturl.at/nABCP.

Chen, Y., Yu, J. and Khan, S. (2010), "Spatial sensitivity analysis of multi-criteria weights in GIS-based land suitability evaluation", Environmental Modelling and Software, vol. 25, no. 12, p. 1582-1591.

Crețu, D. and Demetriu, S. (2006), "Methods for calculation of seismic response in Romanian design codes. Comparisons and Reviews", AICPS Journal, p. 1-9.

Dumitrache, L., Nae, M., Dumbrăveanu, D., Simion, G. and Suditu, B. (2016), "Contrasting Clustering in Health Care Provision in Romania: Spatial and Aspatial Limitations", Procedia Environmental Sciences, vol. 32, p. 290-299.

Duzgun, H.S.B., Yucemen, M.S., Kalaycioglu, H.S., Celik, K., Kemec, S., Ertugay K. and Deniz, A. (2011), "An integrated earthquake vulnerability assessment framework for urban areas", Natural Hazards, vol. 59, no. 2, p. 917-947.

Ianoş, I., Sorensen, A. and Merciu, C. (2017), "Incoherence of urban planning policy in Bucharest: It's potential for land use conflict", Land Use Policy, vol. 60, p. 101-112.

Lang, D, Molina-Palacios, S., Lindholm, C. and Balan, S. (2012), "Deterministic earthquake damage and loss assessment for the city of Bucharest, Romania", Journal of Seismology, vol. 16, no. 1, p. 67-88.

Marmureanu, G., Cioflan, C.O. and Marmureanu, A. (2010), Researches on local seismic hazard (microzonation) for metropolitan Bucharest area, Tehnopress, Iași.

Ministry of Public Works, Development and Administration (2015-2017), Annual program actions for the design and execution of consolidation work to multi-storeyed dwelling buildings, classified by technical expertise report in the first class of seismic risk (red dot buildings), 12 February 2020, shorturl.at/flGIO.

NA (2020), Despre Proiectul ALERT, 20 January 2020, http://seismic-alert.ro//.

National Institute of Statistics, Romania (INS) (2011), Results of the 2011 Population and Housing National Census, 11 January 2018, shorturl.at/hqGUX.

Pavel, F. and Vacareanu, R. (2016), "Scenario-based earthquake risk assessment for Bucharest, Romania", International Journal of Disaster Risk Reduction, vol. 20, p. 138-144. 
Petrișor, A.I., Ianoș, I. and Tălângă, C. (2010), "Land Cover and Use Changes Focused on the Urbanization Processes in Romania", Environmental Engineering E Management Journal, vol. 9, no. 6, p. 765-771.

Romanian Government (1994), Government Ordinance no. 20/1994 on measures for seismic risk reduction on existing constructions, republished

Rufat, S. (2009), "From mural map to GIS: Mapping urban vulnerability in Bucharest" in Urban and regional data management: UDMS, A Krek, M Rumor, S Zlatanova, and E Fendel (eds), Taylor and Francis Group, London, p. 301-313. Șercăianu, M., Nenciu, I., Suditu, B., Neagu, M., Popescu, R. and Murzea, D. (2018), "A Plea for People Centered Perspectives on Seismic Risk Evaluation, Published", in R. Văcăreanu and C. Ionescu (eds.) Seismic Hazard and Risk Assessment, p.313-328, Springer International Publishing.

Toma-Danila, D., Zulfikar, C., Manea, E.F. and Cioflanm C.O. (2015), "Improved seismic risk estimation for Bucharest, based on multiple hazard scenarios and analytical methods", Soil Dynamics and Earthquake Engineering, vol. 73, p. 1-16.

Trendafiloski, G., Wyss, M., Rosset P. and Marmureanu, G. (2009), "Constructing city models to estimate losses due to earthquakes worldwide: Application to Bucharest, Romania", Earthquake Spectra, vol. 25, no. 3, p. 665-685.

World Bank/ Ministry of Regional Development and Public Administration (2015) Efficient, transparent coordination and selection of infrastructure projects funded by structural instruments and state budget for the period 2014-2020, code SMIS 48659 Component 4 "Housing in Romania. Towards a National Housing Strategy", a World Bank study for Romanian Ministry of Regional Development and Public Administration. 